\title{
Methane fluxes measured by eddy covariance and static chamber techniques at a temperate forest in central Ontario, Canada
}

\author{
J. M. Wang ${ }^{1}$, J. G. Murphy ${ }^{1}$, J. A. Geddes ${ }^{1}$, C. L. Winsborough ${ }^{2}$, N. Basiliko ${ }^{2}$, and S. C. Thomas ${ }^{3}$ \\ ${ }^{1}$ University of Toronto, Department of Chemistry, Toronto, Canada \\ ${ }^{2}$ University of Toronto, Department of Geography, Mississauga, Canada \\ ${ }^{3}$ University of Toronto, Faculty of Forestry, Toronto, Canada \\ Correspondence to: J. G. Murphy (jmurphy@chem.utoronto.ca)
}

Received: 20 October 2012 - Published in Biogeosciences Discuss.: 12 December 2012

Revised: 23 May 2013 - Accepted: 24 May 2013 - Published: 28 June 2013

\begin{abstract}
Methane flux measurements were carried out at a temperate forest (Haliburton Forest and Wildlife Reserve) in central Ontario $\left(45^{\circ} 17^{\prime} 11^{\prime \prime} \mathrm{N}, 78^{\circ} 32^{\prime} 19^{\prime \prime} \mathrm{W}\right)$ from June to October 2011. Continuous measurements were made by an off-axis integrated cavity output spectrometer that measures methane $\left(\mathrm{CH}_{4}\right)$ at $10 \mathrm{~Hz}$ sampling rates. Fluxes were calculated from the gas measurements in conjunction with wind data collected by a 3-D sonic anemometer using the eddy covariance (EC) method. Observed methane fluxes showed net uptake of $\mathrm{CH}_{4}$ over the measurement period with an average uptake flux ( \pm standard deviation of the mean) of $-2.7 \pm 0.13 \mathrm{nmol} \mathrm{m}^{-2} \mathrm{~s}^{-1}$. Methane fluxes showed a seasonal progression with average rates of uptake increasing from June through September and remaining high in October. This pattern was consistent with a decreasing trend in soil moisture content at the monthly timescale. On the diurnal timescale, there was evidence of increased uptake during the day, when the mid-canopy wind speed was at a maximum. These patterns suggest that substrate supply of $\mathrm{CH}_{4}$ to methanotrophs, and in certain cases hypoxic soil conditions supporting methanogenesis in low-slope areas, drives the observed variability in fluxes. A network of soil static chambers used at the tower site showed reasonable agreement with the seasonal trend and overall magnitude of the eddy covariance flux measurements. This suggests that soillevel microbial processes, and not abiological leaf-level $\mathrm{CH}_{4}$ production, drive overall $\mathrm{CH}_{4}$ dynamics in temperate forest ecosystems such as Haliburton Forest.
\end{abstract}

\section{Introduction}

Methane $\left(\mathrm{CH}_{4}\right)$ is the predominant hydrocarbon in the atmosphere and the third most important greenhouse gas after water $\left(\mathrm{H}_{2} \mathrm{O}\right)$ and carbon dioxide $\left(\mathrm{CO}_{2}\right)$; its atmospheric abundance has increased by $150 \%$ since the pre-industrial era (Dlugokencky et al., 2009). As of 2010, the radiative forcing of $\mathrm{CH}_{4}$ from anthropogenic emissions was $0.50 \mathrm{~W} \mathrm{~m}^{-2}$, corresponding to approximately $30 \%$ of the radiative forcing from $\mathrm{CO}_{2}$ (Montzka et al., 2011). Estimates of the soil sink for $\mathrm{CH}_{4}$ vary between 15 and $45 \mathrm{Tg} \mathrm{CH}_{4} \mathrm{yr}^{-1}$ (Curry, 2007), making it the second largest sink after tropospheric oxidation. The main losses of atmospheric $\mathrm{CH}_{4}$ in the biosphere are oxidation in upland soils. However, the overall magnitude of the soil sink and the factors governing its variability are not well understood. It is believed that between 30 and $50 \%$ of the global $\mathrm{CH}_{4}$ soil sink is in the temperate zone (Price et al., 2004). Natural $\mathrm{CH}_{4}$ emissions are dominated by methanogenesis in wetlands, especially under conditions of high humidity and temperature. Recently, it has been suggested that plants themselves have the potential to emit $\mathrm{CH}_{4}$ depending on environmental conditions (Keppler et al., 2006; Brüggemann et al., 2009; Wang et al., 2011), although the significance of these emissions in natural environments has been disputed (Nisbet et al., 2009). The uncertainties in the global $\mathrm{CH}_{4}$ budget result from limited observational data coverage and the large variability in the factors that influence $\mathrm{CH}_{4}$ fluxes in natural environments (Heimann, 2011).

Methane surface-atmosphere exchange has been measured using a variety of different approaches, most 
commonly chamber enclosure techniques (Christensen et al., 1995; van Huissteden et al., 2005), eddy covariance techniques (Fan et al., 1992; Verma et al., 1992; Edwards et al., 1994; Hendriks et al., 2008; Detto et al., 2011), flux-gradient techniques (Simpson et al., 1997; Miyata et al., 2000; Edwards et al., 2001), or inferred by $\mathrm{CH}_{4}$ mixing ratio measurements (e.g., Dlugokencky et al., 1994, 2009). Methane flux studies using chamber enclosures and eddy covariance have focused mainly on $\mathrm{CH}_{4}$-emitting ecosystems such as peatlands and other wetlands (Bartlett and Harriss, 1993; Simpson et al., 1995; Meijide et al., 2011; Baldocchi et al., 2012; Hatala et al., 2012). In these ecosystems, $\mathrm{CH}_{4}$-producing microbes (methanogens) are the main $\mathrm{CH}_{4}$ source, and studies have shown that environmental factors such as soil moisture and temperature can control microbial activity (Satpathy et al., 1997). Physical and biological processes, such as ebullition and diffusive emissions through water, and plantmediated transport of $\mathrm{CH}_{4}$ through aerenchyma (Miyata et al., 2000), are known to impact $\mathrm{CH}_{4}$ emission rates. The presence of $\mathrm{CH}_{4}$-oxidizing microbes (methanotrophs) in aerated zones (Mikkelä et al., 1995) with oxic conditions can mediate the emissions of $\mathrm{CH}_{4}$ in these systems.

Forest soils can transition between oxic and anoxic conditions depending on topographic position and environmental conditions, leading to significant variability in local microbial activity and potentially to methane surface flux (Ueyama et al., 2012). Itoh et al. (2009) found that the soil moisture patterns could greatly affect seasonal and spatial variations in $\mathrm{CH}_{4}$ fluxes within a temperate forest: during rainy summers, wetter sites exhibited large $\mathrm{CH}_{4}$ emissions compared to dry areas, which were net sinks of $\mathrm{CH}_{4}$. Forest type, soil moisture, temperature, and $\mathrm{pH}$ have been shown to affect microbial communities involved in $\mathrm{CH}_{4}$ production and oxidation; however, much remains unknown about methanogens and $\mathrm{CH}_{4}$-oxidizing bacteria in forests (Aronson et al., 2012). In past studies, $\mathrm{CH}_{4}$ flux measurements in forests were conducted mainly using the chamber enclosure techniques due to the simplicity and relatively inexpensive nature of the method. Chamber measurements are particularly suitable for process-level studies of components within the ecosystem, such as individual plants or the soil (Keller et al., 1990; Singh et al., 1997). Drawbacks to this technique are that it is labor-intensive, may lack spatial and temporal representativeness, and may be subject to biases arising from soil disturbance and inadequate gas mixing (Christiansen et al., 2011). Simpson et al. (1997) found that at an aspen site, chambers in the tower footprint measured net uptake of $\mathrm{CH}_{4}$; however, flux-gradient measurements showed the forest as a net source due to large sources located in small areas in the forest. This discrepancy stresses the importance of spatial heterogeneity in sources and sinks, and the challenge in upscaling from point measurements within a forest ecosystem. In contrast, the eddy covariance (EC) method integrates fluxes over a larger area, leading to measurements that are more representative of the ecosystem as a whole (Clement et al., 1995). Recent technological advances providing high measurement precision at sampling frequencies of $10-20 \mathrm{~Hz}$ have allowed for the accessibility of the EC technique for measurements of $\mathrm{CH}_{4}$ fluxes. The off-axis integrated output spectrometer (OA-ICOS) has been shown to provide a robust system that meets these requirements (Hendriks et al., 2008) and has been used in previous studies to measure $\mathrm{CH}_{4}$ fluxes (Smeets et al., 2009; Eugster and Plüss, 2010; Parmentier et al., 2011; Querino et al., 2011).

In this paper, we describe growing season flux measurements of $\mathrm{CH}_{4}$ in a mixed deciduous forest in central Ontario, Canada, using an OA-ICOS instrument operating at $10 \mathrm{~Hz}$. Soil-level $\mathrm{CH}_{4}$ exchange within the tower footprint was characterized using small flux chambers along seven toposequences. The flux estimates are also compared with diurnal cycles in the mixing ratio of $\mathrm{CH}_{4}$ to assess the spatial representativeness of the flux values measured by eddy covariance.

\section{Materials and methods}

\subsection{Site description}

Measurements were made at the Haliburton Forest and Wildlife Reserve $\left(45^{\circ} 17^{\prime} 11^{\prime \prime} \mathrm{N}, 78^{\circ} 32^{\prime} 19^{\prime \prime} \mathrm{W}\right)$ located in the Great Lakes/St. Lawrence forest region of Ontario. The forest is an uneven-aged forest managed under selection system silviculture, and the measurement site has not been harvested since 1997, resulting in a heterogeneous canopy structure. The forest region is dominated mainly by Acer saccharum Marsh., Fagus grandifolia Ehrh., Tsuga canadensis L., and Betula alleghaniensis Britt., and contains sandy and acidic soils with a pH of 3.6-5.7 (Peng and Thomas, 2006). The topography near the tower site contains a mix of highlands and valleys ranging in elevation between 380 and $506 \mathrm{~m}$ above sea level ( $m$ a.s.l.). The tower itself is located in a higher elevation area at approximately $500 \mathrm{~m}$ a.s.l., and is surrounded mainly by forest with pockets of small fens, marshes, and lakes located at lower elevations. Measurements were carried out at the top of a $32 \mathrm{~m}$ tower, $8 \mathrm{~m}$ above the canopy. A diesel generator was located $100 \mathrm{~m}$ northeast (usually downwind) of the measurement tower. The generator showed negligible interference for $\mathrm{CH}_{4}$ and $\mathrm{CO}_{2}$ based on simultaneous measurements by a $\mathrm{NO}_{\mathrm{x}} / \mathrm{NO}_{\mathrm{y}}$ chemiluminescence instrument (Air Quality Design Inc., Wheat Ridge, Colorado, USA) that recorded obvious spikes in nitrogen oxides during periods of generator influence.

\subsection{Eddy covariance flux measurements}

Gas measurements were made between 2 June and 24 October 2011 using an OA-ICOS model \#09-0033 Fast Greenhouse Gas Analyzer (FGGA) developed by Los Gatos Research Inc. (Mountain View, California, USA), which provided continuous simultaneous measurements of $\mathrm{CH}_{4}, \mathrm{CO}_{2}$, 
and $\mathrm{H}_{2} \mathrm{O}$ at a response rate of $10 \mathrm{~Hz}$. The FGGA was located in an environmentally controlled building at the bottom of the tower, and an external dry vacuum scroll pump (Varian TriScroll 300, Palo Alto, California, USA) was used to pull air at approximately $30 \mathrm{~L}$ per minute $\left(\mathrm{L} \mathrm{min}^{-1}\right)$ through $38 \mathrm{~m}$ of PVC tubing with an internal diameter of $0.95 \mathrm{~cm}$. In addition to the internal filter, an external filter $(7 \mu \mathrm{m})$ was placed in the inlet line near the instrument; however, the air stream was not dried. A correction factor for the cross-sensitivity to $\mathrm{H}_{2} \mathrm{O}$ in the $\mathrm{CO}_{2}$ and $\mathrm{CH}_{4}$ measurements by the FGGA was determined through external calibration (refer to the Supplement), which results in a calculated $\mathrm{CH}_{4}$ mixing ratio in dry air. The mirror ringdown time remained above $10 \mu$ s during the measurement period, well above the lower limit of $3.5 \mu \mathrm{s}$ defined by the manufacturer. Audits of the FGGA with a gas standard showed good accuracy (within $25 \mathrm{nmol} \mathrm{mol}^{-1}$ ) and stability in the measured mixing ratio (refer to the Supplement), the measurement noise $(2 \sigma)$ for $\mathrm{CH}_{4}$ at $10 \mathrm{~Hz}$ when sampling using the external pump was $40 \mathrm{nmol} \mathrm{mol}^{-1}$. The inlet of the FGGA was positioned $0.7 \mathrm{~m}$ away from the sonic anemometer (model CSAT3, Campbell Scientific Inc., Logan, Utah, USA) used for wind direction and wind speed measurements, and a LI-7500 (LI-COR Inc., Lincoln, Nebraska, USA) open-path (OP) infrared gas analyzer (IRGA) for additional $\mathrm{CO}_{2}$ and $\mathrm{H}_{2} \mathrm{O}$ measurements. These sensors were secured to a pole extended from the top of the tower and directed in a southwesterly direction $\left(215^{\circ}\right)$ to minimize the influence of flow distortions on the flux measurements.

\subsection{Data processing and corrections}

Data processing was carried out using an EC flux program written in Igor Pro (WaveMetrics). Covariances between the vertical wind component and fluctuations in gas concentrations were calculated in intervals of $30 \mathrm{~min}$. Lag time due to sensor separation was calculated for each averaging period by cross-correlating the measured gas mixing ratio with the vertical wind. Maximum correlation between the FGGA and the anemometer was found with a lag of approximately $4 \mathrm{~s}$. Non-horizontal terrain and tilt in the sonic anemometer was corrected for by a 3-D coordinate rotation using the planar fit technique (Wilczak et al., 2001).

Although fluxes are typically less influenced than mixing ratios by random noise, as it should not correlate well with vertical wind variations (Smeets et al., 2009), instrumental noise can still modify the high frequency region of the cospectrum if the noise level is high enough. Instrumental noise was observed to influence the high frequency part of the cospectrum as a result of the high pumping speed shown in Fig. 1. The noise influenced $\mathrm{CH}_{4}$ more than the $\mathrm{CO}_{2}$ gas channel of the FGGA due to a lower signal-to-noise ratio. From the average of 74 daytime cospectra of $\mathrm{CH}_{4}$ and vertical wind, a conservative estimate of the frequency threshold where noise causes a deviation from the ideal cospectrum was determined to be $0.2 \mathrm{~Hz}$. A correction was applied to the

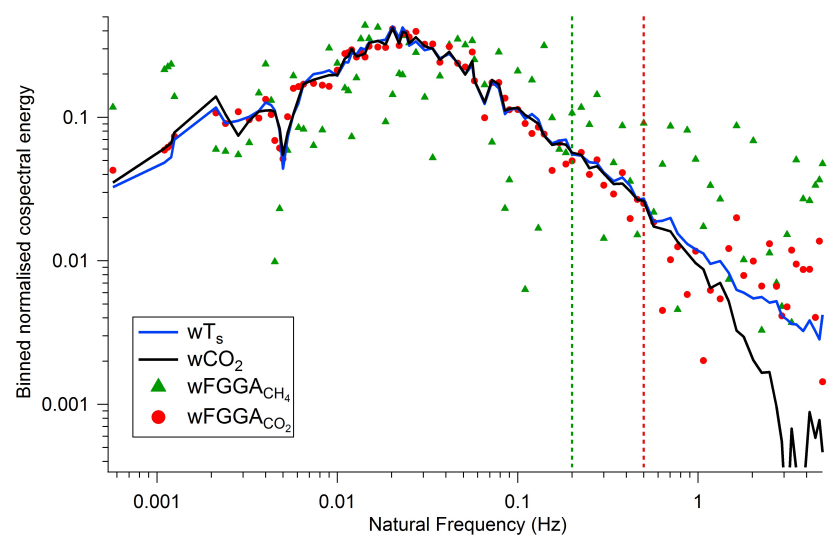

Fig. 1. Averaged smoothed normalized cospectra from 74 daytime ensembles of sonic temperature, an open-path $\mathrm{CO}_{2}$ sensor, and the FGGA $\mathrm{CO}_{2}$ and $\mathrm{CH}_{4}$ plotted as a function of natural frequency with an average stability and wind speed range of $z / L=-0.074$ and $=2.7 \pm 0.5 \mathrm{~m} \mathrm{~s}^{-1}$.

$\mathrm{CH}_{4}$ covariance by multiplying the integrated area up to the cutoff frequency by the ratio of the total integrated area under the temperature cospectrum to its area up to the same cutoff frequency. This resulted in an average decrease in the magnitude of the $\mathrm{CH}_{4}$ flux measurements of $21 \%$.

The contribution of noise in the cospectrum above $0.2 \mathrm{~Hz}$ was also used to evaluate the contribution of noise from the FGGA instrument to the uncertainty of individual flux measurements. To estimate the uncertainty in individual halfhour flux measurements, data were obtained from a calibration in which a stable gas standard was measured by the instrument over $30 \mathrm{~min}$ at high frequency and processed with vertical wind data from the entire measurement period. In theory, if a constant mixing ratio is measured for $30 \mathrm{~min}$ at $10 \mathrm{~Hz}$, the combination of this data with any arbitrary $30 \mathrm{~min}$ of vertical wind data from the sonic anemometer should result in a flux of zero. Histograms of the eddy covariance signals for the entire frequency range, and following the application of the $0.2 \mathrm{~Hz}$ threshold, are shown in Fig. 2. Based on this analysis, we estimate the $2 \sigma$ uncertainty in individual flux measurements to be in the range of $\pm 4 \mathrm{nmol} \mathrm{m}^{-2} \mathrm{~s}^{-1}$.

Non-stationarity was also tested for by splitting each $30 \mathrm{~min}$ interval of data into six periods of $5 \mathrm{~min}$. The average covariance from the six 5 min periods was compared to the $30 \mathrm{~min}$ average, which provided a measure of relative non-stationarity for each flux data point (Foken and Wichura, 1996). Fluxes with a relative non-stationarity larger than $40 \%$ were removed. In post-processing, flux data were then de-spiked for significant outliers by removing values more than eight standard deviations from the average. In addition, flux data from a wind direction of $0-93^{\circ}$ were also removed due to flow distortion that resulted from the tower scaffolding (this also removed a significant fraction of air masses influenced by the generator). The quality control procedures resulted in the removal of approximately $35 \%$ of the $\mathrm{CH}_{4}$ 


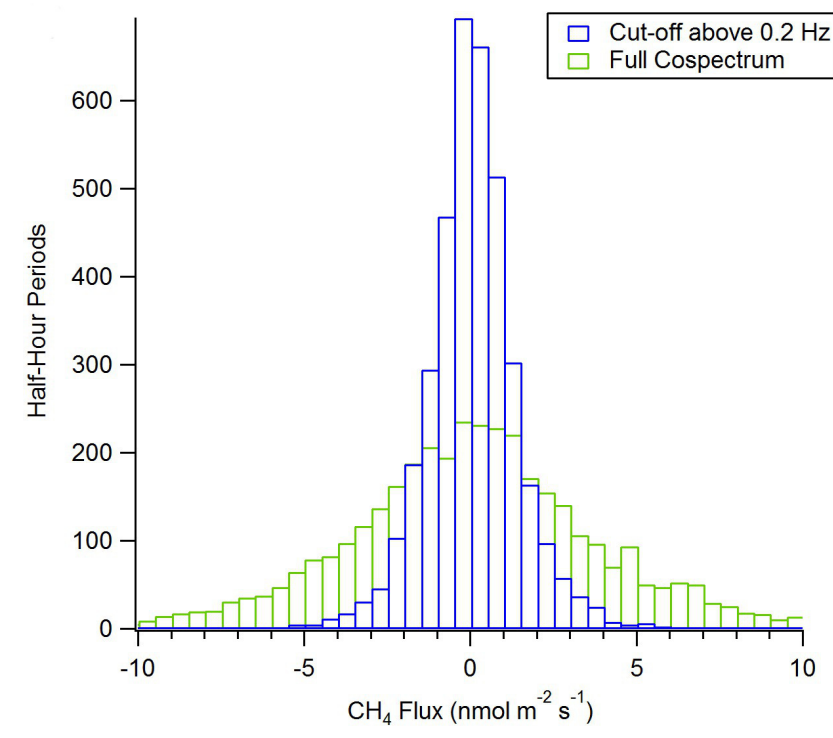

Fig. 2. Histogram of the covariance the entire cospectrum (green) and the contribution above the frequency cutoff of $0.2 \mathrm{~Hz}$ (blue) for $\mathrm{CH}_{4}$ flux calculated from the covariance of a stable sample of calibration gas and the ambient observations of vertical wind from the sonic anemometer.

flux data: non-stationarity test ( $\sim 22 \%$ removed), de-spiking ( 2 points total, $<0.1 \%$ ), and flow distortion data removal $(\sim 13 \%)$.

Webb-Pearman-Leuning (WPL) corrections were not applied during the calculation of the fluxes because dry mixing ratios could be calculated from the FGGA data at high frequency, and because variations in temperature were dampened by the closed-path system. Friction velocity $\left(u^{*}\right)$ cutoffs are typically used in the EC technique to remove the influence of aerodynamic and boundary layer dynamics on fluxes that are expected to be dominated mainly by biologically controlled surfaces. For $\mathrm{CO}_{2}$ fluxes, which are strongly controlled by biological activity of plants in the ecosystem, fluxes affected by low $u^{*}$ are considered artifacts of the EC technique. However, for $\mathrm{CH}_{4}$ fluxes, in addition to biological productivity, the influence of turbulence could potentially be a strong environmental driver in determining variability, as has been proposed in previous studies (Sachs et al., 2008; Wille et al., 2008). Emission fluxes can be missed during periods of low turbulence due to the competing influences of horizontal advection or from storage effects within the canopy; however, uptake is unlikely to be as strongly influenced. Therefore, no friction velocity threshold was applied to the data.

\subsection{Soil chamber measurements}

Static chamber measurements of $\mathrm{CH}_{4}$ were conducted on eight separate days throughout the EC measurement period using a distributed network of soil flux chamber stations es- tablished within the footprint of the tower following Basiliko et al. (2009). An additional intensive measurement campaign was carried out, in which fluxes were measured every $4 \mathrm{~h}$ over $20 \mathrm{~h}$ on 22-23 August 2011. A permanent collection of $10 \mathrm{~cm}$ PVC collars were installed over seven topographical gradients including five sites each: low slope, toe slope, midslope, high slope, and ridge slope. On measurement days, PVC chambers were secured to each collar sealed with a closed cell foam gasket, and $30 \mathrm{~mL}$ was taken four times over a $90 \mathrm{~min}$ period using airtight syringes. The samples were analyzed in the laboratory using gas chromatograph/flame ionization detector (GC-FID) and a packed column (SRI Instruments, Menlo Park, California, USA). The changes in mixing ratio (relative to calibration standards) were used to infer a flux for each site, corrected for chamber temperature and ambient atmospheric pressure at each sampling time. Soil temperature and moisture measurements were also made adjacent to the chamber measurement sites throughout the year using automated DS1921G Thermochron iButtons (Maxim Integrated Products, San Jose, California, USA) and Odyssey Soil Moisture Loggers (Dataflow Systems Pty Ltd., Christchurch, New Zealand). Sensors were located at a $5 \mathrm{~cm}$ soil depth, and each logger recorded hourly average temperatures and volumetric soil moisture measurements respectively. The soil temperature data used in the analysis are the average of measurements from six different sites. Out of two sites measuring soil moisture, only one provided representative measurements, as the second site was situated in a low-slope area that was predominantly wet. With a small percentage of the study area containing such low-slope sites, this was deemed unrepresentative, and the data from the higher slope chamber site were used.

\subsection{Ancillary measurements}

Additional sensors (Onset Computer Corporation, Bourne, Massachusetts, USA) measured temperature, wind direction and speed within the canopy, and amount of rain, which was measured at intervals of 5 min throughout the measurement period. A canister study was also conducted at the tower site 22-24 August 2011 using 6 L stainless steel summa polished canisters (Scientific Instruments Specialists, Moscow, Idaho, USA) with a passive flow controller integrated over $2 \mathrm{~h}$ sampling periods during the day, and between 18:00 and 06:00 LT over the nighttime. Samples were collected at three different levels: near ground $(5 \mathrm{~m})$, mid-canopy $(20 \mathrm{~m})$, and above canopy $(32 \mathrm{~m})$. The samples were brought to the Environment Canada Analysis and Air Quality Section laboratory (AAQS) where the samples were diluted with air and analyzed with a GC-FID 6890 (Agilent, Santa Clara, California, USA) equipped with a $1 \mathrm{~mL}$ sample loop. A Valco Bond (VICI, Gig Harbor, Washington, USA) capillary column (VP-mol sieve 5A, $30 \mathrm{~m}, 0.53 \mathrm{~mm}$ ID, $15 \mu \mathrm{m}$ film thickness) was used to separate $\mathrm{CH}_{4}$. A four-point calibration curve using a $\mathrm{CH}_{4}$ certified reference standard was used to 
determine the concentration of the sample from the peak area of the chromatograms. The dilution factor was then applied to give the proper mixing ratio of $\mathrm{CH}_{4}$.

\section{Results}

\subsection{Methane mixing ratio measurements}

The average methane mixing ratio $( \pm$ one standard deviation) was $1920 \pm 40 \mathrm{nmol} \mathrm{mol}^{-1}$ over the measurement period. The mixing ratio had synoptic scale variations through the measurement period ranging between 1860 and $2080 \mathrm{nmol} \mathrm{mol}^{-1}$. Many of these increases in the methane mixing ratio were observed to match with a southerly wind direction. While local biogenic methane emission sources may be located to the south of the site, a back trajectory analysis (not shown here) indicates that the higher mixing ratios corresponded to air masses that had passed over the populated areas $200 \mathrm{~km}$ to the south with anthropogenic emissions on the order of tens of $\mathrm{nmol} \mathrm{m}^{-2} \mathrm{~s}^{-1}$. Mixing ratio measurements from the FGGA agreed with canister measurements at the top of the tower to within $5 \mathrm{nmol} \mathrm{mol}^{-1}(0.3 \%)$ when averaged over the two-day measurement period.

\subsection{Methane fluxes and environmental measurements}

Over the measurement period, the average flux value ( \pm one standard deviation of the mean) was $-2.7 \pm 0.13 \mathrm{nmol} \mathrm{m}^{-2} \mathrm{~s}^{-1}$ with highly variable fluxes, as shown in Fig. 3. Methane fluxes are expected to be more variable than fluxes of other gases, such as $\mathrm{CO}_{2}$, due to the episodic nature of many of the processes affecting $\mathrm{CH}_{4}$ fluxes (Eugster and Plüss, 2010). For an ecosystem that contains both potential sources and sinks of $\mathrm{CH}_{4}$, this variability is likely to be higher than that of an ecosystem that is predominantly a source. Noise in each individual half-hour measurement (Fig. 1) is another important contributor to the variability seen in Fig. 3. While a significant number of individual flux measurements are not statistically distinguishable from zero, calculation of the $48 \mathrm{~h}$ running average (black line in Fig. 3) demonstrates that there are coherent signatures in the flux time series that emerge through time averaging. Further support for net uptake in the vicinity of the tower comes from the canister measurements at the three levels on the tower, which showed a decrease in mixing ratio from above the forest canopy $(32 \mathrm{~m})$ to the near-ground level $(2 \mathrm{~m})$, with a vertical gradient ranging from 0 to $100 \mathrm{nmol} \mathrm{mol}^{-1}$.

The average of the soil-level fluxes from the multiple sites along the five different topographical gradient positions over the eight measurement dates was $-0.19 \mathrm{nmol} \mathrm{m}^{-2} \mathrm{~s}^{-1}$, also indicating net uptake, but of a smaller magnitude. This calculation was performed assuming equal contribution to the flux footprint from each elevation represented in the topographi-

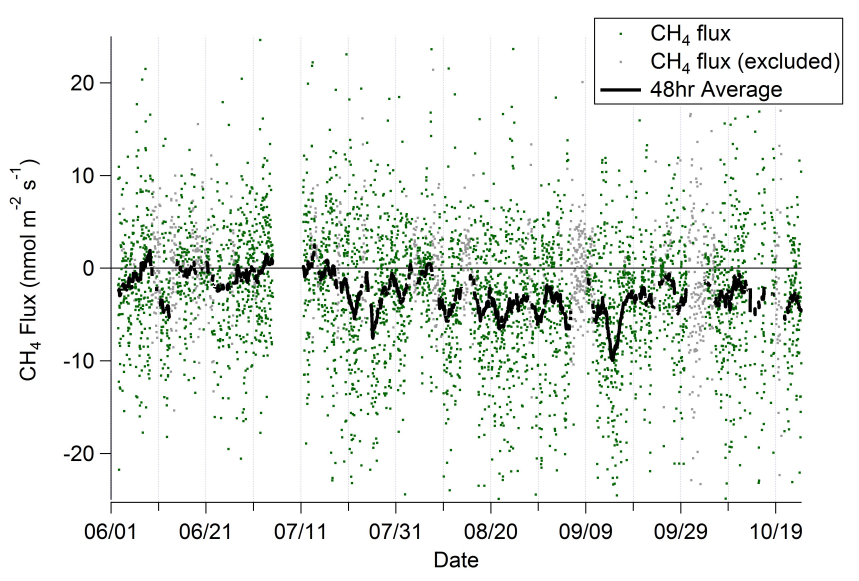

Fig. 3. $\mathrm{CH}_{4}$ flux (green) with excluded data (gray) and limit of detection of individual flux measurements (dashed red) and distribution (right panel) from 2 June to 24 October 2011.

cal gradients. However, using lidar data, the low-slope areas within the tower footprint are estimated to have a percent area contribution of $6.1 \%$. The soil-level fluxes measured from these low-slope areas in June and July represented high emission rates (hundreds of nmol m${ }^{-2} \mathrm{~s}^{-1}$ ), skewing the averages measured from the chambers in these months. After July, chamber fluxes were more consistent, with a net flux of approximately $-2 \mathrm{nmol} \mathrm{m}^{-2} \mathrm{~s}^{-1}$ across all topographical gradients.

The average ambient air and soil temperatures $( \pm 1 \sigma)$ were $11.8 \pm 6.8^{\circ} \mathrm{C}$ and $14.0 \pm 2.8^{\circ} \mathrm{C}$ respectively, during the measurement period of 145 days from 2 June to 24 October 2011. The soil temperature, averaged over six sites, remained relatively constant compared to ambient temperature, even during a cold period lasting over 4 days in midSeptember when ambient temperatures dropped to $-9.0^{\circ} \mathrm{C}$, but soil temperatures remained above $5.0^{\circ} \mathrm{C}$. The soil percent moisture by mass varied between 8 and $100 \%$, with an average value of $60 \%$. Soil moisture was influenced by rain events that dried in subsequent days, and the entire measurement period lacked evidence of a diurnal cycle.

Monthly averages of $\mathrm{CH}_{4}$ fluxes (Table 1) showed an increase in uptake from June at $-1.19 \mathrm{nmol} \mathrm{m}^{-2} \mathrm{~s}^{-1}$ to a peak of $-4.02 \mathrm{nmol} \mathrm{m}^{-1} \mathrm{~s}^{-1}$ in September. Subsequently, in October, rates dropped to an average of $-2.95 \mathrm{nmol} \mathrm{m}^{-2} \mathrm{~s}^{-1}$. Both air and soil temperatures peaked in July and decreased as the season progressed. Soil moisture also had the highest average value in July at $69 \%$ and decreased in September and August. Wind speed remained relatively constant from June through September with higher average wind speeds in October. The wind direction was predominantly northwesterly; however, in September southeasterly conditions were often experienced. The increased mid-canopy wind speed in October can be partly attributed to leaf fall during that 
Table 1. Monthly averages of eddy covariance $\mathrm{CH}_{4}$ fluxes and ancillary measurements.

\begin{tabular}{|c|c|c|c|c|c|c|}
\hline & \multirow{2}{*}{$\begin{array}{c}\mathrm{CH}_{4} \text { flux } \\
( \pm 1 \sigma) \\
\left(\mathrm{nmol} \mathrm{m}^{-2} \mathrm{~s}^{-1}\right)\end{array}$} & \multicolumn{2}{|c|}{$\begin{array}{l}\text { Temperature } \\
\quad\left({ }^{\circ} \mathrm{C}\right)\end{array}$} & \multirow{2}{*}{$\begin{array}{c}\text { Soil } \\
\text { moisture } \\
(\%)\end{array}$} & \multicolumn{2}{|c|}{$\begin{array}{l}\text { Wind speed } \\
\quad\left(\mathrm{m} \mathrm{s}^{-1}\right)\end{array}$} \\
\hline & & Air & Soil & & $\begin{array}{l}\text { Above } \\
\text { canopy }\end{array}$ & $\begin{array}{l}\text { Mid- } \\
\text { canopy }\end{array}$ \\
\hline Jun & $-1.19 \pm 0.24$ & 12.3 & 13.3 & 65 & 2.35 & 0.43 \\
\hline Jul & $-1.66 \pm 0.25$ & 17.1 & 16.2 & 69 & 2.32 & 0.41 \\
\hline Aug & $-3.45 \pm 0.23$ & 14.1 & 15.8 & 59 & 2.29 & 0.41 \\
\hline Sep & $-4.02 \pm 0.26$ & 9.9 & 13.6 & 43 & 2.36 & 0.53 \\
\hline Oct & $-2.95 \pm 0.32$ & 3.8 & 10.1 & 67 & 2.92 & 1.07 \\
\hline
\end{tabular}

month, which allowed the wind to penetrate further within the canopy.

\subsection{Diurnal variability in $\mathrm{CH}_{4}$ mixing ratio and fluxes and in environmental variables}

Methane fluxes averaged over the measurement period showed a diurnal trend (Fig. 4) where fluxes decreased in magnitude between 03:00 and 08:00 with a minimum uptake at $-0.6 \mathrm{nmol} \mathrm{m}^{-2} \mathrm{~s}^{-1}$, and increased in uptake midday between 10:00 and 16:00 at $-4.6 \mathrm{nmol} \mathrm{m}^{-2} \mathrm{~s}^{-1}$. The diurnal trend for $\mathrm{CH}_{4}$ fluxes showed little seasonal variability in terms of timing, though on average tended towards higher overall uptake as the summer season progressed. Mixing ratios also exhibited a diurnal trend reaching a minimum in the midafternoon around 15:00 and with a gradual increase starting at 18:00 that peaked at 06:00 in the early morning. This is shown in Fig. 5, which displays the diurnal cycle in the difference from the daily average, $d \mathrm{CH}_{4}$ $\left(\equiv \mathrm{CH}_{4}(t)-\mathrm{CH}_{4}\right.$ (average)). Figure 6 indicates that the average slope in mixing ratio change each night between 00:00 and 05:00 depends on the average wind direction over that time period. It is evident that $\mathrm{CH}_{4}$ was more likely to accumulate overnight under southerly flow conditions, indicating that important emission areas may be found to the south of the tower.

The diurnal variability in $\mathrm{CH}_{4}$ fluxes and several environmental variables is displayed in Fig. 7. Of the environmental measurements made at the tower, ambient and soil surface temperature (Fig. $5 \mathrm{~b}$ and c), and wind speed above the canopy and within the canopy (mid-canopy) (Fig. 5e and f) showed the strongest diurnal cycles. Soil moisture (Fig. 7d) did not exhibit a significant and consistent diurnal pattern. To investigate if these environmental variables could explain the variability in $\mathrm{CH}_{4}$ flux, scatterplots against soil moisture, and above-canopy and mid-canopy wind speed were made (Fig. 8). Each panel is overlaid with a line of best fit through the entire data set. Additionally, the average $\mathrm{CH}_{4}$ fluxes for narrow bins of the independent variable, limited to where the data density is highest, are used to guide the eye. The relationship is strongest for $\mathrm{CH}_{4}$ flux with the mid-canopy wind

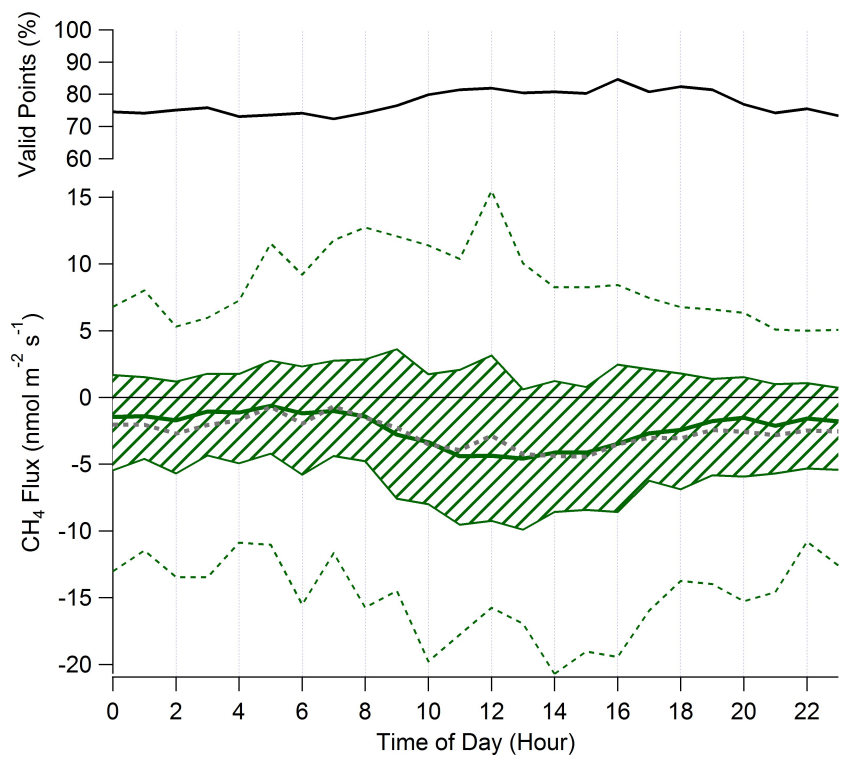

Fig. 4. Median diurnal cycle of percent of valid points within each hour (black) and $\mathrm{CH}_{4}$ fluxes (bold) and average flux (dashed gray), with interquartile range (shaded area), and the 5th and 95th percentile range (indicated by dashed line) over the measurement period.

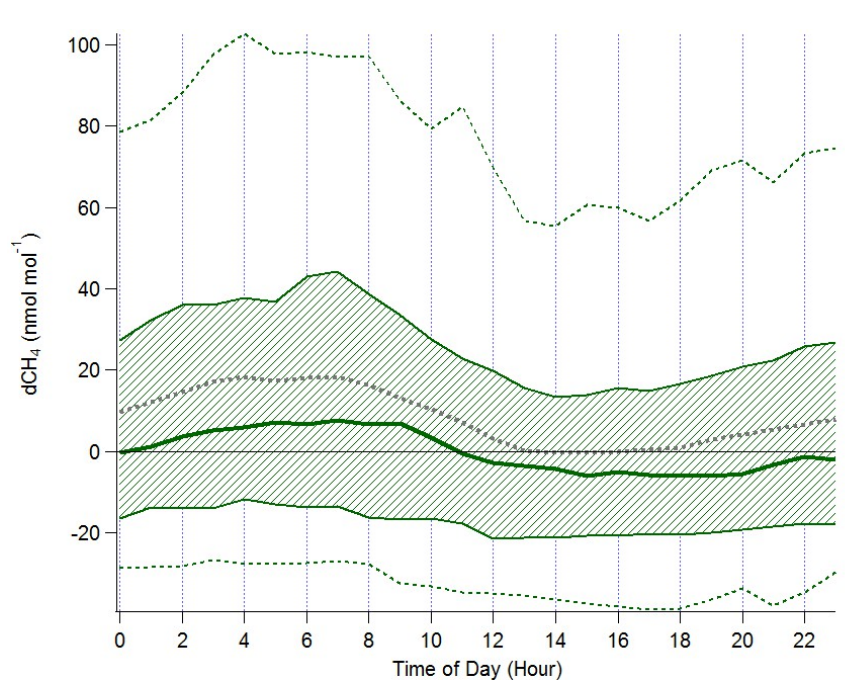

Fig. 5. Mean (gray dashed line) and median (bold green) diurnal cycle of change in $\mathrm{CH}_{4}$ mixing ratio $\left(\mathrm{dCH}_{4}\right)$, with interquartile range (shaded area), and the 5th and 95th percentile range (indicated by green dashed lines) normalized to the median value.

speed (similar diurnal pattern) and with soil moisture, though over longer timescales.

\subsection{Comparison of eddy covariance and chamber flux measurements}

Measurements from the static chambers can help to shed light on the observed seasonal progression of fluxes 


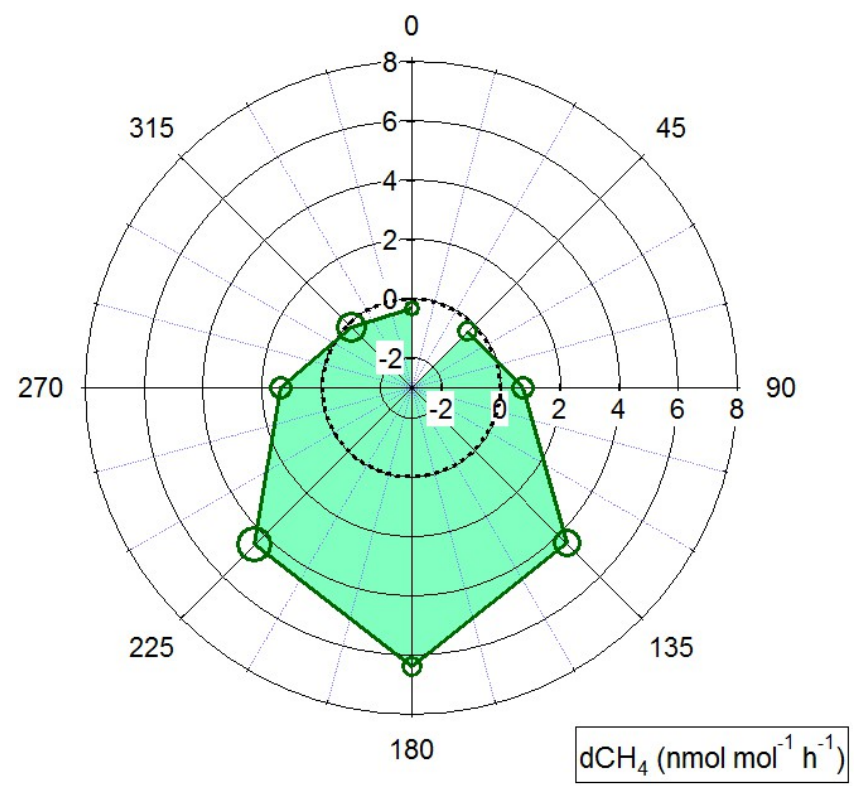

Fig. 6. Polar plot of bin-averaged (each $45^{\circ}$ wind direction) slope of the change in $\mathrm{CH}_{4}$ mixing ratio between 00:00 and 05:00 from each day during the measurement period with each size of the circular markers indicating the number of points within the bin (8-19 points).

measured from the tower, with the lowest net uptake observed in June and July (Table 1). Figure 9 compares the average of the chamber flux measurements with eddy covariance measurements made during the nighttime (22:0007:00) and daytime (08:00-19:00) of the chamber sampling day, and one day on either side. This is effectively comparing a spatial average of the chamber measurements with a time average of the eddy covariance measurements. Based on the EC measurements alone, it was not possible to determine whether the lower net uptake in June and July resulted from reduced methanotrophy or increased methanogenesis. However, the chambers indicate that methanogenesis played a role in limited parts of the tower footprint. For example, on 21 June, six of the seven chambers at low-slope positions showed evidence of emission, averaging $163 \mathrm{nmol} \mathrm{m}^{-2} \mathrm{~s}^{-1}$ (with a range between -3.1 and $+998 \mathrm{nmol} \mathrm{m}^{-2} \mathrm{~s}^{-1}$ ). After the low-slope soils began to dry (August to October), the chamber fluxes at all five topographical gradient positions showed net uptake.

\section{Discussion}

\subsection{Methane mixing ratio and fluxes}

The diurnal amplitude of the mean $\mathrm{CH}_{4}$ mixing ratio is approximately $15 \mathrm{nmol} \mathrm{mol}^{-1}$, corresponding to an increase of $\sim 1.25 \mathrm{nmol} \mathrm{mol}^{-1} \mathrm{~h}^{-1}$ between sunset and sunrise (Fig. 3). One explanation for the observed diurnal trend is the ac-

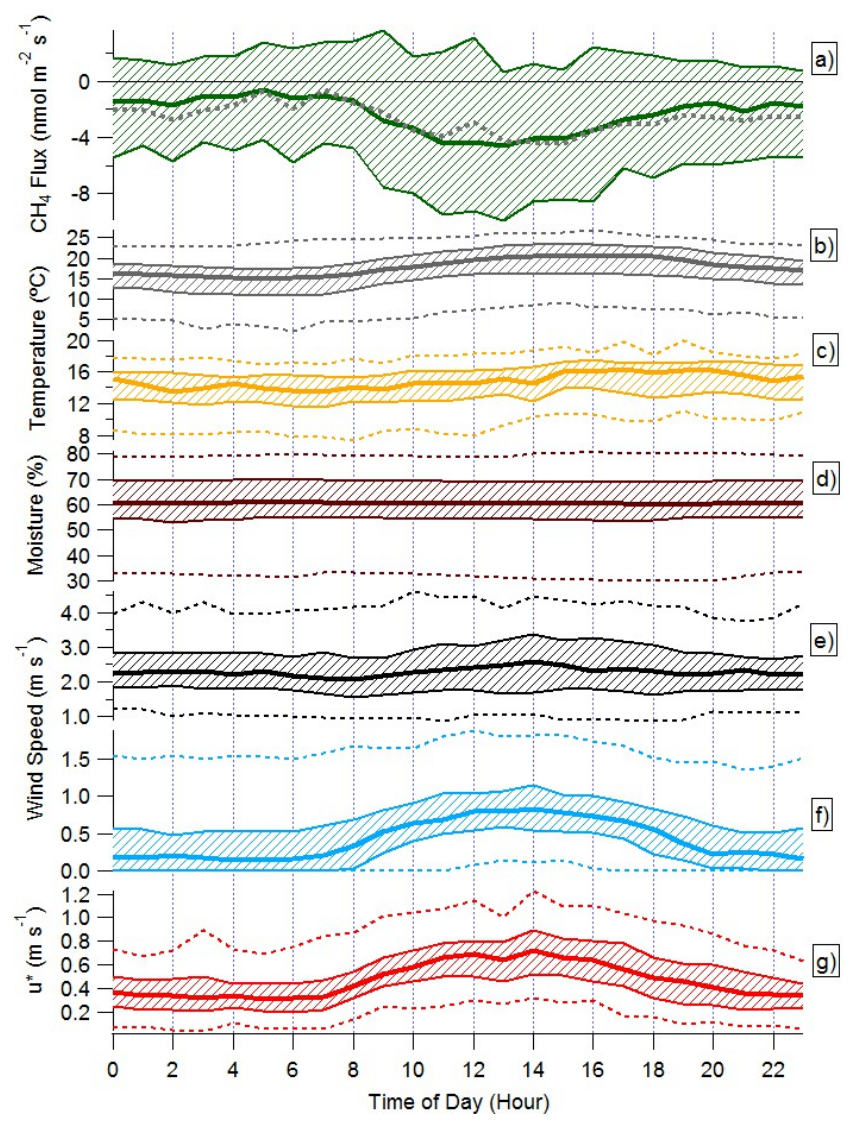

Fig. 7. Median (bold) diurnal cycle of $\mathrm{CH}_{4}$ fluxes with average flux (dashed gray) (a), ambient temperature (b), soil surface temperature (c), soil moisture (d), wind speed above canopy (e), mid-canopy (f), and friction velocity, $u^{*}(\mathrm{~g})$; with interquartile range (shaded area), and the 5th and 95th percentile range (indicated by dashed lines).

cumulation of surface emissions within the shallow stable boundary layer during the night, with the subsequent breakup of the nocturnal boundary layer resulting in the dilution of accumulated $\mathrm{CH}_{4}$ (Culf et al., 1997). If the observed diurnal cycle is the result of a local surface flux, then assuming an arbitrary nocturnal boundary layer height of $100 \mathrm{~m}$, this corresponds to a nighttime emission of $1.4 \mathrm{nmol} \mathrm{m}^{-2} \mathrm{~s}^{-1}$. While this appears at odds with the net uptake calculated by eddy covariance in the flux footprint, the concentration footprint of a tower is much larger than the flux footprint (Vesala et al., 2008), suggesting that emissions may dominate in the areas further upwind of the tower. This is not unexpected, as the study area is a mosaic of lakes, wetlands, and upland forests, with the tower situated at a relatively high elevation.

A rough estimation of the flux footprint was calculated using a footprint parameterization by Kljun et al. (2004) for a $90 \%$ limit of integration using averaged values for surface friction velocity and the standard deviation of vertical velocity fluctuations $\left(\sigma_{\mathrm{w}}\right)$ and with an estimate for the planetary boundary layer height $(h)$. Different model inputs were used 


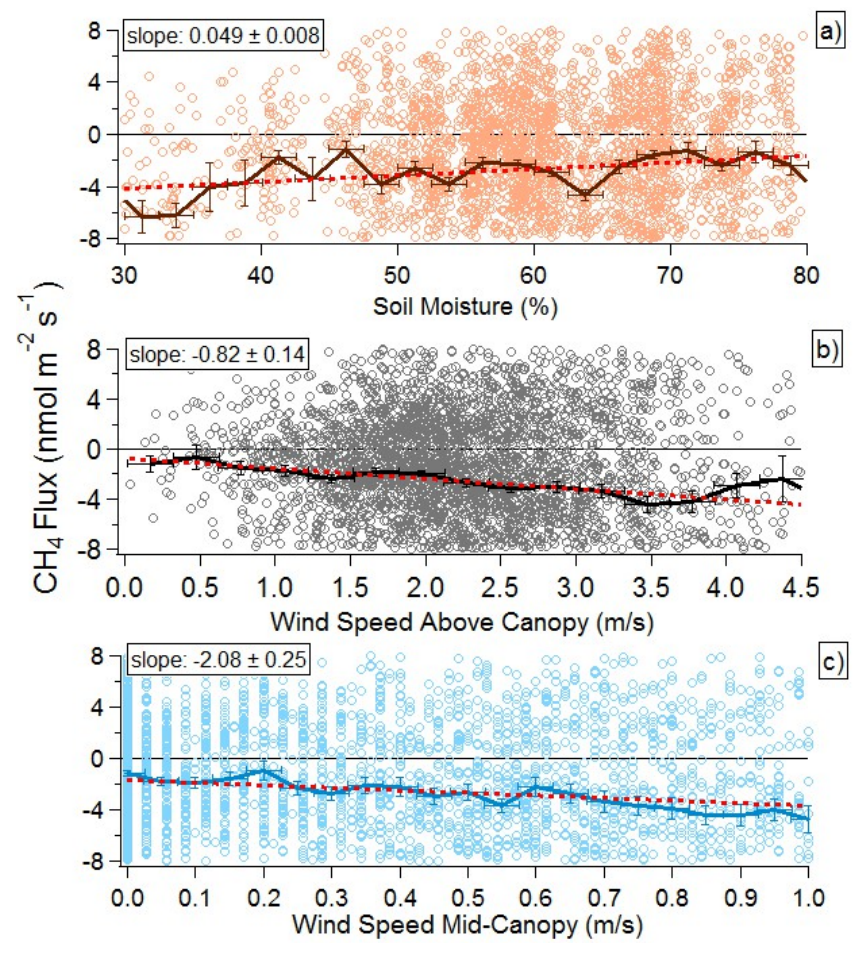

Fig. 8. Scatterplot of $\mathrm{CH}_{4}$ fluxes with soil moisture (a), and wind speed above canopy (b) and mid-canopy (c) with a line of best fit (red dashed line), error bars indicating standard deviation of the mean (vertical), and size of the bin (horizontal). Dashed red line is a linear regression through the data, with the slope $\pm 2 \sigma$ reported for each panel. For each of the three panels, the respective $p$ value is $<0.001$.

for daytime $\left(\sigma_{\mathrm{w}}=0.78, u^{*}=0.60, h=1500 \mathrm{~m}\right)$ and nighttime $\left(\sigma_{\mathrm{w}}=0.47, u^{*}=0.32, h=100 \mathrm{~m}\right)$. The footprint estimate was $574 \mathrm{~m}$ for nighttime and $516 \mathrm{~m}$ for daytime average values. However, nighttime flux footprints did extend further past $\sim 800 \mathrm{~m}$ with low range $u^{*}$ and $\sigma_{w}$ values. With an average flux footprint of $\sim 550 \mathrm{~m}$, this area is much smaller than the expected mixing ratio footprint of the tower (Vesala et al., 2008). The discrepancy between the flux and mixing ratio footprint highlights the difficulty in capturing important land-surface emission and uptake processes from canopyscale observations. Footprint considerations also make it difficult to compare direct observations of $\mathrm{CH}_{4}$ fluxes with model predictions when the footprint is not known precisely (Riley et al., 2011).

\subsection{Dependence of fluxes on environmental variables}

Previous studies in $\mathrm{CH}_{4}$-emitting ecosystems have found that physical processes such as ebullition or diffusive emissions, and biological processes such as plant-mediated transport, have been the main controlling variables in $\mathrm{CH}_{4}$ emissions (Mikkelä et al., 1995; Miyata et al., 2000), resulting in increased emissions during the daytime and decreased emis- sions at night (Satpathy et al., 1997; Miyata et al., 2000; Baldocchi et al., 2012; Hatala et al., 2012). However, the same controlling processes cannot explain the diurnal cycle in $\mathrm{CH}_{4}$ fluxes at Haliburton Forest, given that uptake appears highest during the day. Soil temperature has been shown to affect methanotrophic activity (Reay et al., 2007), though at Haliburton Forest the $\mathrm{CH}_{4}$ fluxes showed a weak relationship with soil temperature.

During the measurement period, soil moisture increased steeply during rain events and decreased in subsequent days, with minimal evidence of a diurnal cycle. An increase in soil moisture decreases air-filled pore space and hence the diffusion of relatively $\mathrm{CH}_{4}$-rich air through the soil to the methanotrophs, decreasing net uptake. If soil moisture levels are high enough to support methanogens, the surface can act as a net emission source of $\mathrm{CH}_{4}$ (Reay et al., 2007). From the scatterplot (Fig. 8a), $\mathrm{CH}_{4}$ fluxes on average increased as soil moisture increased, with a change from an average uptake flux of approximately $-5 \mathrm{nmol} \mathrm{m}^{-2} \mathrm{~s}^{-1}$ below a soil moisture of $40 \%$ to lower uptake fluxes of around $-2 \mathrm{nmol} \mathrm{m}^{-2} \mathrm{~s}^{-1}$ above $68 \%$ soil moisture. From the chamber measurements, there is clear evidence that some low elevation areas in the tower footprint were methane sources, particularly in June and July. While the soil moisture probe did not detect evidence of a diurnal variation in soil moisture measured at $5 \mathrm{~cm}$, it is possible that in the rhizosphere, diurnal variations were more pronounced due to plant activity. For example, Werban et al. (2008) found that soil moisture decreased in the daytime and increased during the nighttime. Similarly, Mikkelä et al. (1995) observed an effect of soil moisture on methanotrophic activity, where oxygen was transported from the atmosphere to the rhizosphere, increasing $\mathrm{CH}_{4}$ microbial oxidation. The position of the soil moisture probe may not have captured the rhizosphere-driven soil water changes, potentially underestimating the diurnal variation in the soil moisture and our interpretation of its influence on microbial $\mathrm{CH}_{4}$ fluxes.

Ambient temperature (Fig. 7b) increased during the day after 08:00 and decreased slowly after 17:00. A similar trend was observed for soil surface temperatures (Fig. 7c); however, the variation in the soil temperature was much smaller and the daytime increase was delayed until 12:00. The influence of temperature variations on $\mathrm{CH}_{4}$ fluxes at the soil level would greatly depend on the depth of microbial community influencing the fluxes. There was no measurement of the vertical distribution of the microbial population in the soil at the Haliburton site, although previous studies have shown that a methanotroph habitat is typically near the surface at $3-15 \mathrm{~cm}$ in depth (Curry, 2007). A scatterplot of $\mathrm{CH}_{4}$ flux with both soil and ambient temperatures (not shown) demonstrated minimal correlation compared to other environmental variables, suggesting that the temperature variations during the measurement period had little effect on $\mathrm{CH}_{4}$ fluxes.

The diurnal cycle of wind speed is most similar to that of $\mathrm{CH}_{4}$ fluxes, with both the wind speed above the canopy 


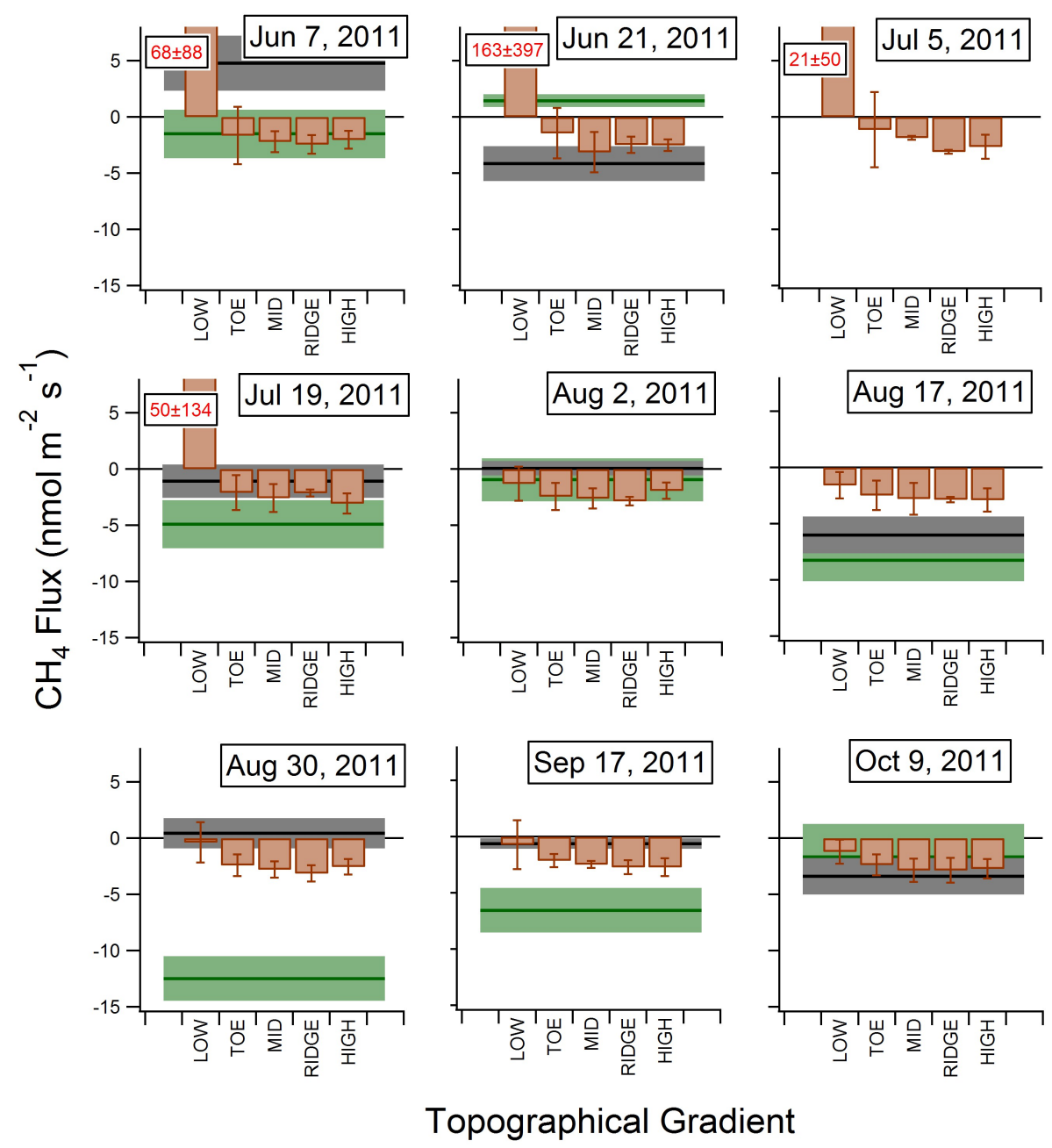

Fig. 9. Bar graph of fluxes calculated from chamber measurements (brown), and EC measurements during the daytime (green) between 08:00 and 19:00 and nighttime (black) between 22:00 and 07:00 for the three days around the chamber measurement. The error bars indicate the standard deviation of the mean within the averaging period for the EC fluxes, or across the sites for the chamber fluxes. No EC measurements were made on 5 July.

(Fig. 7e) and mid-canopy (Fig. 7f) maximizing between 08:00 and 20:00, similar to $\mathrm{CH}_{4}$ uptake. Although at much lower magnitudes, the mid-canopy wind speed showed a more consistent diurnal trend than the wind speed above the canopy. With an increase in mid-canopy wind speed from 0 to $1 \mathrm{~m} \mathrm{~s}^{-1}$, there was a consistent increase in uptake flux from -0.5 to $-4.8 \mathrm{nmol} \mathrm{m}^{-2} \mathrm{~s}^{-1}$ (Fig. 8). The mid-canopy wind speed is likely to be most representative of the impact of atmospheric dynamics on soil-level processes. Previous studies have shown that advection, forced by pressure pumping related to atmospheric turbulence, can increase gaseous flux through the snowpack (Massman et al., 1995) and landfill soils (McBain et al., 2005). The impact of this effect is most significant when the concentration gradients are weak (Massman et al., 1997). Typically this "pressure pumping effect" led to increased emissions in $\mathrm{CO}_{2}$ and $\mathrm{CH}_{4}$ resulting from ebullition or ventilation. In a study over the Siberian tundra, Sachs et al. (2008) observed that increased turbulence and wind speed in non-inundated areas could lead to a higher concentration gradient between the methane-enriched soil and the turbulent boundary layer, thus resulting in an increased diffusive flux. At Haliburton Forest, where uptake appears to dominate emission in the flux footprint of the tower, the concentration gradient is reversed. The soil layer would be relatively methane-depleted compared to the atmospheric boundary layer. Increased aeration in the coarse soils in Haliburton Forest may facilitate transport of $\mathrm{CH}_{4}$-rich air from the overlying atmosphere to the methanotrophs and/or transport of $\mathrm{CH}_{4}$-depleted air out of the soil into the atmosphere. Yonemura et al. (2000) observed wind-induced acceleration of gas transport in topsoil that could have played a role in gas uptake, where lower levels of uptake were observed during lower wind speed conditions. 
The driving forces of monthly-scale variations in $\mathrm{CH}_{4}$ fluxes were found to be different than for the diurnal trends. Wind speed remained relatively constant until October, when fall storms and a lack of a developed canopy likely contributed to an increase in wind speed (Table 1). However, $\mathrm{CH}_{4}$ uptake decreased in October despite increased wind speed. This could have been the result of decreases in air and soil temperatures, and/or increased rain events that occurred in October, which could have reduced overall rates of microbial activity and limited rates of $\mathrm{CH}_{4}$ and $\mathrm{O}_{2}$ diffusion to aerobic methanotrophs. Additionally, the new leaf litter on the forest floor in October may have impeded the ventilation of the soils, despite the higher mid-canopy wind speed. The strongest environmental correlation with $\mathrm{CH}_{4}$ fluxes on monthly scales was soil moisture: as the soils progressively dried from June when the soil moisture was the highest, the uptake of $\mathrm{CH}_{4}$ increased, reaching a peak in September.

\subsection{Comparison of eddy covariance and chamber flux measurements}

Early in the season, both the chamber and EC measurements indicate a small net flux, whereas in the months of August and September, both techniques indicate significant uptake, though the daytime EC flux values have a much higher magnitude. As chamber measurements were made in the daytime, this suggests a potential underestimation of $\mathrm{CH}_{4}$ uptake rates due to the chamber blocking the wind, effectively shutting off the supply of $\mathrm{CH}_{4}$ to soil methanotrophs. While increased $\mathrm{CH}_{4}$ uptake as a result of higher wind speed has not been widely reported in previous studies, it may be an important consideration for static chamber measurements that are conducted in enclosed containers with flow restrictions or a lack of proper headspace mixing (Davidson et al., 2002; Christiansen et al., 2011). The better agreement between the magnitudes of the nighttime EC fluxes (lower wind speed) and the chamber measurements is suggestive of such an artifact in the chamber measurements, though certainly not conclusive evidence. A comparison between the tower-based EC measurements and the soil-level chamber measurements can also be used to investigate the presence of any significant aboveground $\mathrm{CH}_{4}$ fluxes. Given that the canopy-level rates of $\mathrm{CH}_{4}$ uptake are, if anything, higher than the soil-level rates of uptake, there is little evidence of an abiological plant source of $\mathrm{CH}_{4}$ at Haliburton Forest.

\section{Summary and conclusions}

Methane fluxes inferred from tower measurements above the canopy and chamber measurements at the soil level indicate that the area of forest in the flux footprint is a net sink for $\mathrm{CH}_{4}$. This was further supported by vertical gradients of $\mathrm{CH}_{4}$ mixing ratios measured at three levels of the tower during two days of the measurement campaign. A diurnal trend was evident throughout the campaign with highest net uptake during the day and decreased uptake during the night. The diurnal cycle of $\mathrm{CH}_{4}$ fluxes was most similar to the diurnal cycle in mid-canopy wind speed. The correlation of $\mathrm{CH}_{4}$ uptake with wind speed can be interpreted to result from the increased substrate supply to methanotrophs in the soil. At monthly timescales, soil moisture content appeared to be the major control on $\mathrm{CH}_{4}$ fluxes. Chamber measurements indicate that high soil moisture could lead to hypoxic conditions and microbial methanogenesis at low elevation sites. Soil moisture may also influence the flux by limiting diffusion rates of substrate to soil methanotrophs. From measurements in August-October, daytime averaged EC fluxes were up to 4 times higher in net uptake than in chamber fluxes. However, when tower fluxes were averaged from the nighttime of the same period, the chamber and tower flux values were much closer. This suggests that static chambers may underestimate the magnitude of uptake within coarse soils if wind-driven ventilation is an important factor. It can also be concluded that plant-level $\mathrm{CH}_{4}$ production, proposed by Keppler et al. (2006), does not detectably influence $\mathrm{CH}_{4}$ dynamics in Haliburton Forest. The average net uptake of $-2.7 \mathrm{nmol} \mathrm{m}^{-2} \mathrm{~s}^{-1}$ is equivalent to $2.8 \mathrm{mg} \mathrm{C} \mathrm{m}^{-2} \mathrm{~d}^{-1}$ (as $\mathrm{CH}_{4}$ ). However from a greenhouse mitigation perspective, it is also interesting to note that, using the $20 \mathrm{yr}$ time horizon global warming potential of methane (72), this uptake is equivalent to $73 \mathrm{mg} \mathrm{C} \mathrm{m}^{-2} \mathrm{~d}^{-1}$ (as $\mathrm{CO}_{2}$ ). Based on conventional quality control criteria, the estimated net carbon uptake of $\mathrm{CO}_{2}$ over the same period in 2011 ranges between 69 and $558 \mathrm{mg} \mathrm{C} \mathrm{m}^{-2} \mathrm{~d}^{-1}$, for nighttime $u^{*}$ thresholds of 0.4 to $0.2 \mathrm{~m} \mathrm{~s}^{-1}$, respectively.

\section{Supplementary material related to this article is available online at: http://www.biogeosciences.net/10/ 4371/2013/bg-10-4371-2013-supplement.pdf.}

Acknowledgements. This work was funded by the Ontario Ministry of the Environment. Additional infrastructure support was provided by the Natural Sciences and Engineering Research Council of Canada Research Tools and Instrument grant, the Canada Foundation for Innovation, and the Ontario Research Fund. Lidar data were provided by the Ministry of Natural Resources, and digital terrain analysis was performed by Murray Richardson. Geoffrey Stupple assisted in site logistics and a geographical survey. Thanks to Peter Schleifenbaum and the Haliburton Forest and Wildlife Reserve staff.

Edited by: G. Wohlfahrt 


\section{References}

Aronson, E. L., Vann, D. R., and Helliker, B. R.: Methane flux response to nitrogen amendment in an upland pine forest soil and riparian zone, J. Geophys. Res., 117, G03012, doi:10.1029/2012JG001962, 2012.

Baldocchi, D., Detto, M., Sonnentag, O., Verfaillie, J., Teh, Y. A., Silver, W., and Kelly, N. M.: The challenges of measuring methane fluxes and concentrations over a peatland pasture, Agr. Forest Meteorol., 153, 177-187, 2012.

Bartlett, K. B. and Harriss, R. C.: Review and assessment of methane emissions from wetlands, Chemosphere, 26, 261-320, 1993.

Basiliko, N., Khan, A., Prescott, C. E., Roy, R., and Grayston, S. J.: Soil greenhouse gas and nutrient dynamics in fertilized western Canadian plantation forests, Can. J. Forest Res., 39, 1220-1235, 2009.

Brüggemann, N., Meier, R., Steigner, D., Zimmer, I., Louis, S., and Schnitzler, J.-P.: Nonmicrobial aerobic methane emission from poplar shoot cultures under low-light conditions, New Phytol., 182, 912-918, 2009.

Christensen, T. R., Jonasson, S., Callaghan, T. V., and Havström, M.: Spatial variation in high-latitude methane flux along a transect across Siberian and European tundra environments, J. Geophys. Res., 100, 21035-21045, 1995.

Christiansen, J., Korhonen, J., Juszczak, R., Giebels, M., and Pihlatie, M.: Assessing the effects of chamber placement, manual sampling and headspace mixing on $\mathrm{CH}_{4}$ fluxes in a laboratory experiment, Plant Soil, 343, 171-185, 2011.

Clement, R. J., Verma, S. B., and Verry, E. S.: Relating chamber measurements to eddy correlation measurements of methane flux, J. Geophys. Res., 100, 21047-21056, 1995.

Culf, A. D., Fisch, G., Malhi, Y., and Nobre, C. A.: The influence of the atmospheric boundary layer on carbon dioxide concentrations over a tropical forest, Agr. Forest Meteorol., 85, 149-158, 1997.

Curry, C. L.: Modeling the soil consumption of atmospheric methane at the global scale, Global Biogeochem. Cy., 21, GB4012, doi:10.1029/2006GB002818, 2007.

Davidson, E. A., Savage, K., Verchot, L. V., and Navarro, R.: Minimizing artifacts and biases in chamber-based measurements of soil respiration, Agr. Forest Meteorol., 113, 21-37, 2002.

Detto, M., Verfaillie, J., Anderson, F., Xu, L., and Baldocchi, D.: Comparing laser-based open- and closed-path gas analyzers to measure methane fluxes using the eddy covariance method, Agr. Forest Meteorol., 151, 1312-1324, 2011.

Dlugokencky, E. J., Masaire, K. A., Lang, P. M., Tans, P. P., Steele, L. P., and Nisbet, E. G.: A Dramatic Decrease in the GrowthRate of Atmospheric Methane in the Norther-Hemisphere During 1992, Geophys. Res. Lett., 21, 45-48, 1994.

Dlugokencky, E. J., Bruhwiler, L., White, J. W. C., Emmons, L. K., Novelli, P. C., Montzka, S. A., Masarie, K. A., Lang, P. M., Crotwell, A. M., Miller, J. B., and Gatti, L. V.: Observational constraints on recent increases in the atmospheric $\mathrm{CH}_{4}$ burden, Geophys. Res. Lett. , 36, L18803, doi:10.1029/2009GL039780, 2009.

Edwards, G. C., Neumann, H. H., den Hartog, G., Thurtell, G. W., and Kidd, G.: Eddy correlation measurements of methane fluxes using a tunable diode laser at the Kinosheo Lake tower site during the Northern Wetlands Study (NOWES), J. Geophys. Res.,
99, 1511-1517, 1994.

Edwards, G. C., Dias, G. M., Thurtell, G. W., Kidd, G. E., Roulet, N. T., Kelly, C. A., Rudd, J. W. M., Moore, A., and HalfpennyMitchell, L.: Methane Fluxes from a Wetland using the FluxGradient Technique The Measurement of Methane Flux from a Natural Wetland Pond and Adjacent Vegetated Wetlands using a TDL-Based Flux-Gradient Technique, Water Air Soil Poll., 1, 447-454, 2001.

Eugster, W. and Plüss, P.: A fault-tolerant eddy covariance system for measuring $\mathrm{CH}_{4}$ fluxes, Agr. Forest Meteorol., 150, 841-851, 2010.

Fan, S. M., Wofsy, S. C., Bakwin, P. S., Jacob, D. J., Anderson, S. M., Kebabian, P. L., McManus, J. B., Kolb, C. E., and Fitzjarrald, D. R.: Micrometeorological Measurements of $\mathrm{CH}_{4}$ and $\mathrm{CO}_{2}$ Exchange Between the Atmosphere and Subarctic Tundra, J. Geophys. Res., 97, 16627-16643, 1992.

Foken, T. and Wichura, B.: Tools for quality assessment of surfacebased flux measurements, Agr. Forest Meteorol., 78, 83-105, 1996.

Hatala, J. A., Detto, M., and Baldocchi, D. D.: Gross ecosystem photosynthesis causes a diurnal pattern in methane emission from rice, Geophys. Res. Lett., 39, L06409, doi:10.1029/2012GL051303, 2012.

Heimann, M.: Atmospheric science: Enigma of the recent methane budget, Nature, 476, 157-158, 2011.

Hendriks, D. M. D., Dolman, A. J., van der Molen, M. K., and van Huissteden, J.: A compact and stable eddy covariance set-up for methane measurements using off-axis integrated cavity output spectroscopy, Atmos. Chem. Phys., 8, 431-443, doi:10.5194/acp-8-431-2008, 2008.

Itoh, M., Ohte, N., and Koba, K.: Methane flux characteristics in forest soils under an East Asian monsoon climate, Soil Biol. Biochem., 41, 388-395, 2009.

Keller, M., Mitre, M. E., and Stallard, R. F.: Consumption of atmospheric methane in soils of central Panama: Effects of agricultural development, Global Biogeochem. Cy., 4, 21-27, 1990.

Keppler, F., Hamilton, J. T. G., Braß, M., and Rockmann, T.: Methane emissions from terrestrial plants under aerobic conditions, Nature, 439, 187-191, 2006.

Kljun, N., Calanca, P., Rotach, M., and Schmid, H.: A Simple Parameterisation for Flux Footprint Predictions, Bound.-Lay. Meteorol., 112, 503-523, 2004.

Massman, W. J., Sommerfeld, R. A., Zeller, K., Hehn, T., Hudnell, L., and Rochelle, S. G.: $\mathrm{CO}_{2}$ flux through a Wyoming seasonal snowpack: diffusional and pressure pumping effects., in: Biogeochemistry of Seasonally Snow-Covered Catchments, edited by: Tonnessen, K. A., Williams, M. W., and Tranter, M., 228, IAHS Press, Wallingford, UK, 71-79, 1995.

Massman, W. J., Sommerfeld, R. A., Mosier, A. R., Zeller, K. F., Hehn, T. J., and Rochelle, S. G.: A model investigation of turbulence-driven pressure-pumping effects on the rate of diffusion of $\mathrm{CO}_{2}, \mathrm{~N}_{2} \mathrm{O}$, and $\mathrm{CH}_{4}$ through layered snowpacks, J. Geophys. Res., 102, 18851-18863, 1997.

McBain, M. C., Warland, J. S., McBride, R. A., and Wagner-Riddle, C.: Micrometeorological measurements of $\mathrm{N}_{2} \mathrm{O}$ and $\mathrm{CH}_{4}$ emissions from a municipal solid waste landfill, Waste Manage. Res., 23, 409-419, 2005.

Meijide, A., Manca, G., Goded, I., Magliulo, V., di Tommasi, P., Seufert, G., and Cescatti, A.: Seasonal trends and environ- 
mental controls of methane emissions in a rice paddy field in Northern Italy, Biogeosciences, 8, 3809-3821, doi:10.5194/bg8-3809-2011, 2011.

Mikkelä, C., Sundh, I., Svensson, B. H., and Nilsson, M.: Diurnal Variation in Methane Emission in Relation to the Water Table, Soil Temperature, Climate and Vegetation Cover in a Swedish Acid Mire, Biogeochemistry, 28, 93-114, 1995.

Miyata, A., Leuning, R., Denmead, O. T., Kim, J., and Harazono, Y.: Carbon dioxide and methane fluxes from an intermittently flooded paddy field, Agr. Forest Meteorol., 102, 287-303, 2000.

Montzka, S. A., Dlugokencky, E. J., and Butler, J. H.: Non- $\mathrm{CO}_{2}$ greenhouse gases and climate change, Nature, 476, 43-50, 2011.

Nisbet, R. E. R., Fisher, R., Nimmo, R. H., Bendall, D. S., Crill, P. M., Gallego-Sala, A. V., Hornibrook, E. R. C., López-Juez, E., Lowry, D., Nisbet, P. B. R., Shuckburgh, E. F., Sriskantharajah, S., Howe, C. J., and Nisbet, E. G.: Emission of methane from plants, P. Roy. Soc. Lond. B, 276, 1347-1354, doi:10.1098/rspb.2008.1731, 2009.

Parmentier, F. J. W., van Huissteden, J., van der Molen, M. K., Schaepman-Strub, G., Karsanaev, S. A., Maximov, T. C., and Dolman, A. J.: Spatial and temporal dynamics in eddy covariance observations of methane fluxes at a tundra site in northeastern Siberia, J. Geophys. Res., 116, G03016, doi:10.1029/2010JG001637, 2011.

Peng, Y. and Thomas, S. C.: Soil $\mathrm{CO}_{2}$ efflux in uneven-aged managed forests: temporal patterns following harvest and effects of edaphic heterogeneity, Plant Soil, 289, 253-264, 2006.

Price, S. J., Sherlock, R. R., Kelliher, F. M., McSeveny, T. M., Tate, K. R., and Condron, L. M.: Pristine New Zealand forest soil is a strong methane sink, Glob. Change Biol., 10, 16-26, 2004.

Querino, C. A. S., Smeets, C. J. P. P., Vigano, I., Holzinger, R., Moura, V., Gatti, L. V., Martinewski, A., Manzi, A. O., de Araújo, A. C., and Röckmann, T.: Methane flux, vertical gradient and mixing ratio measurements in a tropical forest, Atmos. Chem. Phys., 11, 7943-7953, doi:10.5194/acp-11-79432011, 2011.

Reay, D., Hewitt, C. N., Smith, K., and Grace, J.: Greenhouse Gas Sinks, CABI, Oxfordshire, 2007.

Riley, W. J., Subin, Z. M., Lawrence, D. M., Swenson, S. C., Torn, M. S., Meng, L., Mahowald, N. M., and Hess, P.: Barriers to predicting changes in global terrestrial methane fluxes: analyses using CLM4Me, a methane biogeochemistry model integrated in CESM, Biogeosciences, 8, 1925-1953, doi:10.5194/bg-8-19252011, 2011.

Sachs, T., Wille, C., Boike, J., and Kutzbach, L.: Environmental controls on ecosystem-scale $\mathrm{CH}_{4}$ emission from polygonal tundra in the Lena River Delta, Siberia, J. Geophys. Res.-Biogeo., 113, G00A03, doi:10.1029/2007JG000505, 2008.

Satpathy, S. N., Rath, A. K., Ramakrishnan, B., Rao, V. R., Adhya, T. K., and Sethunathan, N.: Diurnal variation in methane efflux at different growth stages of tropical rice, Plant Soil, 195, 267-271, 1997.
Simpson, I. J., Thurtell, G. W., Kidd, G. E., Lin, M., DemetriadesShah, T. H., Flitcroft, I. D., Kanemasu, E. T., Nie, D., Bronson, K. F., and Neue, H. U.: Tunable diode laser measurements of methane fluxes from an irrigated rice paddy field in the Philippines, J. Geophys. Res., 100, 7283-7290, 1995.

Simpson, I. J., Edwards, G. C., Thurtell, G. W., den Hartog, G., Neumann, H. H., and Staebler, R. M.: Micrometeorological measurements of methane and nitrous oxide exchange above a boreal aspen forest, J. Geophys. Res., 102, 29331-29341, 1997.

Singh, J. S., Singh, S., Raghubanshi, A. S., Singh, S., Kashyap, A. K., and Reddy, V. S.: Effect of soil nitrogen, carbon and moisture on methane uptake by dry tropical forest soils, Plant Soil, 196, 115-121, 1997.

Smeets, C. J. P. P., Holzinger, R., Vigano, I., Goldstein, A. H., and Röckmann, T.: Eddy covariance methane measurements at a Ponderosa pine plantation in California, Atmos. Chem. Phys., 9, 8365-8375, doi:10.5194/acp-9-8365-2009, 2009.

Ueyama, M., Hamotani, K., Nishimura, W., Takahashi, Y., Saigusa, N., and Ide, R.: Continuous measurement of methane flux over a larch forest using a relaxed eddy accumulation method, Theor. Appl. Climatol., 109, 461-472, doi:10.1007/s00704-012-0587-0, 2012.

van Huissteden, J., Maximov, T. C., and Dolman, A. J.: High methane flux from an arctic floodplain (Indigirka lowlands, eastern Siberia), J. Geophys. Res., 110, G02002, doi:10.1029/2009JG001040, 2005.

Verma, S. B., Ullman, F. G., Billesbach, D., Clement, R. J., Kim, J., and Verry, E. S.: Eddy correlation measurements of methane flux in a northern peatland ecosystem, Bound.-Lay. Meteorol., 58, 289-304, 1992.

Vesala, T., Kljun, N., Rannik, Ü., Rinne, J., Sogachev, A., Markkanen, T., Sabelfeld, K., Foken, T., and Leclerc, M. Y.: Flux and concentration footprint modelling: State of the art, Environ. Pollut., 152, 653-666, 2008.

Wang, Z.-P., Xie, Z.-Q., Zhang, B.-C., Hou, L.-Y., Zhou, Y.-H., Li, L.-H., and Han, X.-G.: Aerobic and Anaerobic Nonmicrobial Methane Emissions from Plant Material, Environ. Sci. Technol., 45, 9531-9537, 2011.

Werban, U., Attia al Hagrey, S., and Rabbel, W.: Monitoring of rootzone water content in the laboratory by $2 \mathrm{D}$ geoelectrical tomography, J. Plant Nutr. Soil Sc., 171, 927-935, 2008.

Wilczak, J., Oncley, S., and Stage, S.: Sonic Anemometer Tilt Correction Algorithms, Bound.-Lay. Meteorol., 99, 127-150, 2001.

Wille, C., Kutzbach, L., Sachs, T., Wagner, D., and Pfeiffer, E.-M.: Methane emission from Siberian arctic polygonal tundra: eddy covariance measurements and modeling, Glob. Change Biol., 14, 1395-1408, 2008.

Yonemura, S., Miyata, A., and Yokozawa, M.: Concentrations of carbon monoxide and methane at two heights above a grass field and their deposition onto the field, Atmos. Environ., 34, 5007$5014,2000$. 